\title{
The Influence of Entrepreneurship, Creativity and Business Location on Business Success
}

\author{
Alkusani \\ Management Study Program, Faculty of Economics and Business, \\ Universitas Muhammadiyah Gresik, East Java, Indonesia \\ alkusani@umg.ac.id
}

\section{Rida Ilmafa'ati}

Management Study Program, Faculty of Economics and Business

Universitas Muhammadiyah Gresik, East Java, Indonesia

\begin{abstract}
ABSTRAK
Usaha Mikro, Kecil dan Menengah (UMKM) merupakan salah satu bagian penting dari perekonomian suatu negara atau daerah. Peran penting ini mendorong banyak negara termasuk Indonesia untuk terus mengembangkan UMKM. Meski dalam skala kecil jumlah tenaga kerja, aset dan omzet, namun karena jumlahnya yang cukup besar, peran UMKM cukup penting dalam menunjang perekonomian. Keberhasilan UMKM menjadi salah satu faktor pendukung kemajuan berbagai usaha baik mikro, kecil maupun menengah khususnya di Kota Gresik. Penelitian ini bertujuan untuk mengetahui pengaruh jiwa kewirausahaan, kreativitas dan lokasi usaha terhadap keberhasilan usaha. UKM. Metode yang digunakan dalam penelitian ini adalah metode kuantitatif, populasi penelitian ini adalah 51 UKM. Teknik analisis yang digunakan adalah analisis regresi linier berganda dilanjutkan dengan uji $t$ dengan taraf signifikan 0,05. Hasil penelitian menunjukkan bahwa jiwa kewirausahaan, kreativitas dan lokasi usaha secara individu dan simultan berpengaruh signifikan terhadap keberhasilan usaha.
\end{abstract}

Kata Kunci: Jiwa kewirausahaan, kreativitas, lokasi usaha dan keberhasilan usaha.

\begin{abstract}
Micro, small and medium enterprises (UMKM) is one important part of the economy of a country or region. This important role has encouraged many countries including Indonesia to continue to develop UMKM. Although small in scale the number of workers, assets and turnover, but because of the large enough amount, the role of UMKM is quite important in supporting the economy. The success of UMKM is a factor supporting the improvement of various businesses, both micro, small and medium enterprises, especially in Gresik City. This study aims to determine the effect of entrepreneurial spirit, creativity and business location on the business success. of UKM. The method used in this research is quantitative method, the population of this research is 51 UKM. The analysis technique used is multiple linear regression analysis followed by $t$ test with significance level 0,05. The results showed that the entrepreneurial spirit, creativity and business locations individually and simultaneous significantly affect the business success.
\end{abstract}

Keywords: entrepreneurial spirit, creativity, business location and business success.

\section{INTRODUCTION}

Micro, small and medium enterprises (MSMEs) are an integral part of the national business world which has a very strategic position, potential and role in realizing national development goals (Tambunan, 2006). With the existence of the UMKM sector, unemployment due to the labor force that is not absorbed in the world of work is reduced, the MSME sector has also proven to be a strong economic pillar (Ministry of Finance, 2015). The MSME sector was able to withstand the monetary crisis that occurred in Indonesia in 1998. Based on data 
from the Ministry of Cooperatives and MSMEs (2016), the number of MSMEs in 2016 in Indonesia was 57.89 million units, or $99.99 \%$ of the total number of national business actors.

Data from the Central Statistics Agency of East Java Province in 2016 stated that the growth in the production of MSMEs in East Java in the fourth quarter increased by $2.66 \%$ compared to the third quarter. The average development of MSMEs in East Java is 54.34\% per year and accommodates $98 \%$ of the workforce.

MSMEs play a role in economic growth, reduce unemployment, poverty and foreign exchange earnings (SWA, 2014). Data from the East Java Province Industry and Trade Office in 2016 states that the development of business units shows an increasing trend, until the first quarter of 2016 the number of business units increased by $0.50 \%$ from 2013 with the number of workers absorbed by $3,134,809$ people. The following is the data on the development of MSMEs in East Java for the 2013-2016 Period:

Table 1: Development of MSMEs in East Java for the Period 2013-2016

\begin{tabular}{|l|r|r|r|r|}
\hline $\begin{array}{l}\text { Entreprene } \\
\text { urs }\end{array}$ & 2013 & 2014 & 2015 & 2016 \\
\hline $\begin{array}{l}\text { Small } \\
\text { Industry }\end{array}$ & 779,090 & 785,906 & 789,837 & 789,957 \\
\hline $\begin{array}{l}\text { Industry } \\
\text { Medium }\end{array}$ & 16,387 & 16,484 & 16,566 & 16,863 \\
\hline $\begin{array}{l}\text { Large } \\
\text { Industry }\end{array}$ & 1,060 & 1,064 & 1,075 & 1,083 \\
\hline \begin{tabular}{l} 
Total \\
\hline
\end{tabular} & 796,537 & 803,454 & 807,478 & 807,903 \\
\hline
\end{tabular}

Source: Data Diskoperindag of East Java

Province

The Small and Medium Enterprises (SME) sector plays an important role in encouraging regional economic growth. With the existence of the SME sector, unemployment due to the labor force that is not absorbed in the world of work is reduced.

The SME sector has also proven to be a strong economic pillar (www.kemenkeu.go.id).
The economy of Gresik Regency experienced a growth of $6.15 \%$ in 2015 . Based on the relative position of Gresik to East Java, Gresik's economic growth was above the East Java economy, which experienced a growth of $5.44 \%$ in 2015 . This condition is in line when viewed from its relative position. Gresik against the national level in 2015 which grew by 4.79 percent. The Gresik economy is known as one of the main industrial areas in East Java, both small and large-scale industries (www.suaragresik.com).

Several industrial areas that have developed in Gresik Regency are Manyar, Bungah, Sidayu, and Dukun Districts, each of which has industrial business different fields.

The following is a table of the number of industrial business fields from 4 Districts in Gresik Regency which are in areas industrial :

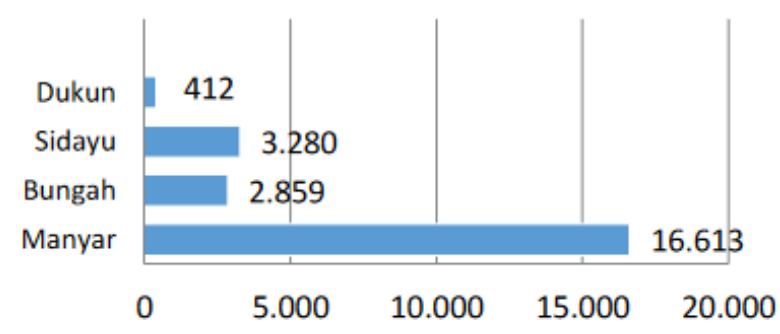

Source: (www.gresikkab.bps.go.id)

Figure 1: Number of Industrial Business Fields in Manyar, Bungah, Sidayu, and Dukun Districts

From Figure 1 it can be seen that the highest number of industrial business fields is in Manyar sub-district, amounting to 16,613 industrial businesses. This shows that the population in Manyar sub-district, which is an industrial area, is more interested in entrepreneurship compared to other subdistricts, both small and medium scale businesses.

In Manyar District itself, there is a village complex that is currently quite busy with many small and medium enterprises that are there, namely Pondok Permata Suci village or better known as village (PPS). 
Pondok Permata Suci (PPS) is a new area that is currently being actively developed by BLP Property (PT Bumi Lingga Pertiwi). Located in an area not far from GKB (Gresik Kota Baru), this is now the most potential area in Gresik. now more than 12,000 people have settled in PPS. The development of the BLP property business in the future for PPS village itself will be based on 5 main pillars, namely: education, community, environment, tourism and entrepreneurship. Based on the five pillars, in the Entrepreneurial Pillar PT BLP will develop an area that provides a place to encourage and grow new entrepreneurs who will later strengthen the nation's economy and increase mutual prosperity (blp-property.com).

With the establishment of shop houses and the availability of Suci Central Market, which is located in the PPS village complex, it is a good opportunity for entrepreneurs to open businesses, especially in the culinary business sector.

Culinary is a part of life that is closely related to daily food consumption. Culinary is a lifestyle that cannot be separated from everyday life, because everyone needs food that is very much needed, from simple food to high-class and luxurious food. With the development of the culinary industry lately, it can indeed be a separate opportunity for Small and Medium Enterprises located in PPS Village. In addition, the factors that support the development of Small and Medium Enterprises (UKM) are a strategic place.

Seeing the large number of Small and Medium Enterprises in the culinary field in PPS village, it can be said that the sales intensity has good prospects so that there is a lot of business competition in this place.

Table 2: Number of Culinary Businesses in PPS

\begin{tabular}{|l|c|}
\hline Year & Culinary Businesses \\
\hline 2014 & 28 \\
\hline 2015 & 37 \\
\hline 2016 & 47 \\
\hline 2017 & 62 \\
\hline \multicolumn{2}{|l|}{ Source: Data from the Village Office of Suci Desa }
\end{tabular}

From the data in table 2 above, it can be seen that the culinary business units in PPS village from the past three years to 2017 have increased. From these data it can also be concluded that the culinary business opportunities in PPS Village are quite good. However, the success rate of the business is very much dependent on the right strategy by the business owner to win the competition in getting as many consumers as possible.

From the results of preliminary observations, there are problems experienced by several culinary entrepreneurs at PPS Village. Some of them admit that it is difficult to develop their business. The occurrence of a difficult phenomenon in developing a business indicates that there is uncertainty in the success of the business of culinary SMEs in PPS village. One of the factors that make it difficult for some culinary entrepreneurs to develop their business is their lack of creativity in making the products they produce. This is recognized by several culinary entrepreneurs at PPS by seeing their products have never changed anything and they still continue to rely on what already exists.

One of the reasons for culinary business actors is a lack of confidence and are not ready to take the risks that will be experienced in their efforts to improve their products. In this case, it can be said that the problem faced by culinary entrepreneurs in PPS village is the lack of positivity in an effort to develop their business to be more advanced and successful.

In addition, business location is also one of the reasons why it is difficult for some culinary business actors to develop their own businesses. Some culinary business actors think the location they use is less strategic, so they admit that so far their sales have not matched their expectations.

The focus of this research is to look at several factors that determine the success of an entrepreneur in running his business. Based on the background description above, the writer is interested in taking the title "The Influence of Entrepreneurship, Creativity and Business Location on Business Success. 


\section{LITERATURE REVIEW}

There is a previous research by Fitria Lestari (2013) entitled" The Influence of Entrepreneurship and Creativity on Business Success in industrial centers. Knitted Binong Jati Bandung ". The purpose of this study was to determine (1) The influence of entrepreneurial spirit on the success of the business at the industrial center of Knitted Binong Jati Bandung. (2) The influence of creativity on the success of business in the industrial center of Knitting Binong Jati Bandung. (3) The influence of entrepreneurial spirit and creativity on the success of the business at the industrial center of Knitting Binong Jati Bandung. The results showed that there was a significant influence between entrepreneurial spirit and creativity on the success of the business at the industrial center of Knitting Binong Jati Bandung.

\section{Small and Medium Enterprises (UKM)}

Small and Medium Enterprises UKM is a term that refers to a type of small business that has a net worth of at most Rp. 200,000,000 excluding land and buildings for business premises. And a stand-alone business. According to Presidential Decree No. 99 of 1998, the definition of Small Business is: "Small scale economic activities of the people with business fields that are predominantly small business activities and need to be protected to prevent unfair business competition." (Pujiyanti, 2015; 67).

\section{Entrepreneurship}

Soegoto $(2009$; 3) Entrepreneurship is a creative business that is built on innovation to produce something new, has added value. Provide benefits, create jobs and the results are useful for others. Meanwhile, Buchari Alma (2007; 52-53) argues that entrepreneurship must be someone who is able to see the future. Looking ahead does not mean empty daydreaming but seeing, thinking calculatingly, looking for options from various alternative problems and solutions.

\section{Entrepreneurial Spirit}

Suryana $(2017 ; 22)$ entrepreneurship can be seen from various aspects of personality such as a person's soul, character, attitudes and behavior. According to Eddy Soeryanto Soegoto $(2009 ; 3)$ entrepreneurship is a person with a creative and innovative spirit who is able to establish, build, develop, advance, and make his company superior.

Nickels in Lestari $(2013 ; 12)$ to obtain these abilities an entrepreneur must have an entrepreneurial spirit, namely:

1. Directing himself

Entrepreneurs should be pleasant and have discipline high self-even though they are business owners and are responsible for the success and failure of the business.

2. Confidence

Entrepreneurs must believe in the ideas they get even if no one thinks of them, and must complement the entrepreneur's enthusiasm.

3. Action-oriented

An extraordinary business idea is not enough without a passion for realizing, actualizing, and making dreams come true.

4. Energetic

This is your business, and you have to be emotionally, mentally, and physically able to work long and hard.

5. Tolerant of uncertainty.

Entrepreneurs succeed by taking calculated risks.

\section{Characteristics of Entrepreneurial Spirit}

Suryana $(2017 ; 22)$ a person who has an entrepreneurial spirit must have the following characteristics:

1. Full of confidence

2. Have the initiative

3. Have an achievement motive

4. Have a leadership spirit

5. Dare to take risks

Creativity

Suryana $(2017$; 66) Creativity is thinking something new and different (thinking new 
things). Creativity is the ability to develop new ideas and ways of solving problems and finding opportunities (Suryana, 2017; 15). Campbell $(2012 ; 11)$ states that creativity is an activity that produces results that are new, innovative, unprecedented, fresh, interesting, strange, surprising and useful. Creative people always work systematically by presenting relevant data and information.

The creative person is one who is always thinking about the novelty, Difference, usefulness and intelligibleSuryana, 2017; 66).

Entrepreneurs use the right brain to learn develop creative skills (Suryana, 2017: 66). Creativity is not only important for creating a competitive advantage, but also very important for company continuity (Suryana, 2017; 71).

\section{Creativity Process}

To generate creativity requires a process with certain steps, namely as follows (Zimmerer in Suryana, 2017; 67):

1. Preparation Preparatory steps are intended to provide conditions for someone to facilitate the emergence of creativity. This can be done through education formal, training, and work experience. To prepare creative thinking, very supportive things must be done as follows: Continuous learning, reading a lot about anything, not limited to the discipline itself and from various sources, making clippings. Then try to discuss it even with people under you or other fields, because sometimes those who are not experts in the field that you are good at, ask stupid questions, but give rise to bright ideas. Try to become a member of an association / association, learn the culture of another nation or ethnicity, increase the ability to listen, especially to older people and a lot of experience.

2. Investigation

The second step, investigation. In this case, study the problem and identify the main components of the problem.

3. Transformation
The third step of transformation. Try to identify the similarities and differences that exist with the information and data that has been collected here, it can apply divergent and convergent analysis. Convergent Thinking is the ability to see similarities and relationships between various information and events. Divergent Thinking is the ability to see the difference,

4. Hatching

The fourth step of hatching. It will take time to review various information. The incubation period occurs as if someone leaves or forgets the problem at hand.Walk away from the situation, an expert suggested three b's - bath, bed, and bus, this activity is very conducive to creating creativity. This thoughtless atmosphere sometimes results in very creative thinking. Do it relax and relax, don't think about the problem continuously, but forget about it for a while, often creative thoughts arise when we are exercising, exercising, in the garden, in the garden, etc. Or you try to do work in another place that you don't normally work there, this atmosphere will generate creative ideas.

5. Illumination

The fifth step of Illumination. This step occurs at the time of incubation, spontaneously emerging new ideas. This step appears indefinitely, it can appear suddenly, usually when you have forgotten the problem.

6. Testing

The sixth step of testing. To validate an idea that is right or accurate, whether it is useful or not, experiments are carried out, make simulations, test the market for products, make pilot projects and so on.

7. Implementation of Implementation The seventh step. It begins to transform ideas into reality and use. Here applies the expression ready, aim, shoot, not ready, aim, aim, aim, aim, never shoot. 


\section{Characteristics of Creative People}

Suryana $(2017 ; 73)$ creative people have the following characteristics:

1. Challenged with existing circumstances

2. Always curious

3. Have high motivation

4. Imagine

5. raising crazy ideas

6. Dare to face risks

7. Like to seek inspiration

8. Have an interest in What is amazing

\section{Business Locations}

Locations that have criteria in accordance with customer expectations are locations that can answer the extent to which a service is able to react to the economic situation. The location that is attractive to consumers is the most strategic location, pleasant and efficient (Suryana, 2017; 209).

Location is one of the elements contained in the retail mix. In the retail business, location has been an important element in building a business strategy for a long time.

Location or place also does not only represent a convenience that consumers will get according to Kotler (2009; 94-95), location or place must also be able to market or promote itself.

\section{Factors Affecting Location Attractiveness}

Utami $(2014 ; 145)$ The problems that make a certain location have a specific attractiveness. Observing the advantages of location accessibility and the advantages of location as the center:

1. Accessibility, a location is a convenience for consumers to come or enter and leave the location. The analysis has two stages:

a. Macro analysis

Considering the primary trading area, the location at the retail macro level simultaneously evaluates several factors such as road patterns, road conditions and obstacles.

b. Micro analysis
Concentrates on issues around the site, such as visibility, traffic flow, parking, crowds and entrances or exits.

2. Advantages of location within a center After the accessibility of the center has been evaluated, the analyst must evaluate the location within it. This is because a better location costs more, retailers must consider their interests. Another consideration is to locate attractive stores against the target market share that are close to each other. In essence, consumers want to shop where they find a complete variety of merchandise.

Tjiptono in Aprih Santoso, and Sri Widiowati (2011; 184) Business Location indicators are as follows:

1. Location affordability

2. Smooth access to locations

3. Proximity to location

\section{Business Success}

Noor $(2007$; 397) states that business success is essentially the success of the business achieving its goals, a business is said to successful when it gets a profit, because profit is the goal of a person doing business. According to Albert Wijaya in Suryana (2011; 168) which states that a factor which is a critical goal and a measure of the success of a company is profit.

Tambunan $(2002 ; 14)$ the factors that influence business success can be seen from two factors, namely internal factors and external factors. Internal factors including; human resources quality, organizational mastery, organizational structure, management system, participation, business culture / culture, capital strength, business networks with outsiders, and the level of entrepreneurship.

External factors can be divided into two, namely government and non-government factors. Government factors include economic policy, bureaucrats, politics, and the level of democracy. Non-government factors, namely; economic system, socio-culture, society, system 
of labor and conditions, labor, the condition of the infrastructure,the level of public education, and the global environment.

Business success is the main part of a company where all activities in it are aimed at achieving success. In a general sense, success shows a situation that is better or superior than the previous period. In accordance with this opinion, it can be concluded that a business is said to be successful if it has an advantage over the previous period or with companies in its class.

Some indicators in determining the success of the business, according to Henry Faizal Noor $(2007$; 397) is as follows:

1. Income (profitability)

Profit is the main goal of the business operating profit is the difference between revenue and biaya.pendapatan an enterprise comes from the sale of goods and services produced or produced.

2. Productivity and efficiency

The productivity of an enterprise will greatly determine the size of the size of a production. This will affect the size of a sale and in the end determine the size of the income, thus affecting the size of the earned. Meanwhile, the costs incurred by the company to obtain goods and services that become its business depends on the efficient level of the product, the higher the efficiency, the lower the production costs incurred, and vice versa.

3. Competitiveness

Competitiveness is the ability or toughness to compete for consumer attention and loyalty. A business can be said to be successful, if it can beat competitors or at least still survive against competitors. Customer attention and loyalty can be won if a company can satisfy a consumer's needs and desires. Without adequate competitiveness, it is difficult for companies to survive in the midst of increasingly fierce competition. Therefore, the core of the competitiveness that a company must have is the ability to innovate to create and seize new market opportunities that have sprung up in society.

4. Competence and business ethics

Competence is the accumulation of knowledge, research results and experiences quantitatively and qualitatively in the field so that it can produce innovations in accordance with the demands of the times. Competence needs to be improved and adapted to the developments taking place so that the company maintain can its competitive edge while business ethics is the behavior in the conduct of the business which can be broadly defined as conduct business does not harm the interests of other people, both individuals and groups of the public to be able to maintain competitiveness or the advantages it already has, the company needs to take care of it through two important things, namely continuously improving competence and simultaneously suppressing ethics in doing business.

5. The development of a good image

The company's good image is divided into two, namely: internal thrust and external thrust. Trust Internalis a trust or thrust of all the people in the company. Indicators of the growth of internal thrust are low employee absenteeism, low employee turnover, increasing company productivity and efficiency and so on.

Meanwhile, external thrust is the emergence of trust or trust from all stakeholders company, be it consumers, suppliers, government or the wider community, even competitors. The indicators are the building of a good company image, increased sales, low levels of complaints, increased orders, and so on.

\section{Relationship the Entrepreneurial Spirit on Business Success}

Suryana $(2017 ; 22)$ entrepreneurship can be seen from various aspects such as personality, spirit, character, attitude and behavior. According to Eddy Soeryanto 
Soegoto $(2009 ; 3)$ entrepreneurship is a person with a creative and innovative spirit who is able to establish, build, develop, advance, and make his company superior.

With this understanding, it can be concluded that entrepreneurial spirit has a positive relationship with business success.

\section{The Relationship between Creativity and Business Success}

Alma (2009; 72) Creativity is very important to create competitive advantage and business survival. With this understanding, it can be concluded that creativity has a positive relationship with business success.

\section{The relationship between Business Location and Business Success}

Foster $(2008 ; 51)$, store location greatly affects the level of profitability and business success in the long term. With this understanding, it can be concluded that business location has a positive relationship with business success.

\section{Hypothesis}

Based on the background and existing problems, it is directed to refer to provisional assumptions, namely:is

1. Entrepreneurial spirit partially influences the success of culinary SMEs

2. Creativity partially influences the success of culinary SMEs

3. Business location partially influences the success of culinary SMEs

4. The spirit of entrepreneurship, creativity and business location have a simultaneous effect on the success of culinary SMEs

\section{METHODE}

The approach used in this study is quantitative. The location in this study was carried out at the PPS village (Pondok Permata Suci), Suci Village, Manyar District, Gresik Regency.

The population in this study were 62 culinary SMEs in PPS Village (Pondok Permata
Suci), Suci Village, Manyar District, Gresik Regency.

The sampling technique used is a Probability Sampling, sampling which provides equal opportunities for each element (member) of the population to be selected as a sample member Sugiyono (2017; 82). By using the Simple Random Sampling type, it is said to be simple because the sampling of sample members from the population is done randomly without paying attention to the strata in the population. (Sugiyono, 2017; 82).

Sugiyono $(2017 ; 86)$ states that the number of samples from a certain population developed from Isaac and Michael, if the population is 62 people and an error rate of $5 \%$, the sample used is 51 respondents. The sample in this study were 51 culinary SMEs in pps village.

Measurement of the variables used in this study is to use the Likert scale. (Sugiyono, 2017; 93) With a Likert scale, the variables to be measured become variable indicators. The Likert scale is used to measure attitudes, opinions and perceptions of a person or group of people about social phenomena. The Likert scale used in this study is a Likert scale of 1-5. Primary data in this study were obtained by distributing questionnaires to the owners of the Kuliner UKM in the PPS village of Suci, Manyar District, Gresik Regency.

The data collection technique in this study used a questionnaire, which is a data collection technique by distributing a questionnaire or a list of questions to respondents in order to get more detailed information and data about the problem being researched. The expected answer in this study has been provided so that the respondent just needs to choose the answer that is considered appropriate. This study uses hypothesis testing using statistical tests, namely through regression analysis. This technique is to determine the effect of each independent variable having a positive or negative effect on the dependent variable and to predict the value of the dependent variable if the value of the independent variable has increased or decreased. 


\section{RESULTS AND DISCUSSION}

\section{General Description of the Research Object}

Pondok Permata Suci (PPS) is a new area that is currently being actively developed by BLP Property (PT Bumi Lingga Pertiwi) in Gresik Regency. Located in an area not far from GKB (Gresik Kota Baru), this is now the most potential area in Gresik. Now more than 12,000 people have settled in PPS.

The development of the BLP property business in the future for PPS itself will be based on 5 main pillars, namely: education, community, environment, tourism and entrepreneurship. And based on the five pillars, in the Entrepreneurial Pillar PT BLP will develop an area that provides a place to encourage and grow new entrepreneurs who will later strengthen the nation's economy and increase mutual prosperity (blp-property.com).

The Small and Medium Enterprises (SME/UKM) sector plays an important role in driving the growth of the Indonesian economy. Small and Medium Enterprises (UKM) are business actors engaged in various business fields, which touch the interests of the community. With the development of the culinary industry lately, it can indeed be a separate opportunity for Small and Medium Enterprises located in PPS. In addition, the factors that support the development of Small and Medium Enterprises (UKM) are a strategic place.

The objects in this study were 51 owners of culinary UKM in PPS (Pondok Permata Suci), Suci Village, Manyar District, Gresik Regency. The limitations of this study are as follows:

1. The dependent variable (dependent) is business success and the independent variable (free) is entrepreneurial spirit, creativity and business location.

2. The sample used as the research object was 51 owners of culinary UKM in the PPS (Pondok Permata Suci) in Suci Village, Manyar District, Gresik Regency.
3. The research location is in the PPS (Pondok Permata Suci), Suci Village, Manyar District, Gresik Regency.

4. The data collection technique in this research is a questionnaire method used to collect data related to Entrepreneurial Spirit, creativity and business location in culinary SMEs.

\section{Data Analysis \\ Validity Test}

In this study a questionnaire was used to collect research data. A questionnaire is said to be valid if the questions on the questionnaire are able to reveal something that will be measured by the questionnaire. In this validity test, a statement item or variable is declared valid if $r$ count is greater than $r$ table. From the results of the instrument validity test, all variables obtained rcount $>$ rtable 0.276 . So all questions from the independent and dependent variables are proven valid.

\section{Reliability Test}

A variable is said to be reliable or reliable if a person's answer to a statement is consistent or stable over time. In this reliability test, a variable item is said to be valid if $r$ alpha is greater than $r$ table. Based on data processing, it shows that for each variable the value Cronbach Alpha is greater than 0.60. Thus it can be concluded that the measuring instrument used in this study is reliable.

\section{Classical Assumption Test}

Normality Test

Normality test aims to test whether in the regression model, confounding or residual variables have a normal distribution or not (Ghozali, 2006). The analytical tool used in this test is the Kolmogorov-Smirnov test. This test tool is used to provide more detailed figures to confirm whether there is normality or not from the data used.

Normality occurs when the results of the test are Kolmogorov-Smirnov more than 0.05 (Ghozali, 2006). The data normality test was 
performed using the Kolmogorov Smirnov test and the PP plot standardized residuals approaching the diagonal line, so the data were distributed normally. In principle, normality can be detected by looking at the distribution of data (points) on the diagonal axis of the graph or by looking at the histogram of the residual.

From the results of the KolmogorovSmirnov test, it can be seen that the data is distributed normally because it has a significance probability value above 0.05 . Based on the existing output, it is known that the significance value of 0.431 is greater than 0.05 , so it can be concluded that the data tested is normally distributed.

\section{Multicollinearity Test}

Multicollinearity is a situation where there is multicorrelation between one independent variable and another or in other words, a relationship between one variable and another can be formed between the independent variables. A good regression model does not contain a correlation between the independent variables. The relationship between independent variables is free from multicollinearity if it has a tolerance value > 0.10 and VIF <10.From the results of data management, it is obtained that the tolerance value is greater than 0.10 and VIF is less than 10 , so it can be concluded that the regression model has no problems. multicollinearity.

\section{Heteroscedasticity Test}

A good regression model is homoscedasticity or heteroscedasticity does not occur. To determine the presence or absence of heteroscedasticity is a graph plot between the predicted value of the dependent variable and its residual. Heteroscedasticity detection can be done by looking at the presence or absence of certain patterns on the scatterplot graph. If there is no clear pattern, such as dots spread above and below point 0 on the $\mathrm{Y}$ axis. The result of the heteroscedasticity test is that there is no heteroscedasticity because the dots are perfectly spread out and do not form a pattern.

\section{Multiple Linear Regression Analysis}

This analysis is used to determine whether the variables of entrepreneurial spirit, creativity and business location have an effect on the business success of culinary SMEs in PPS

This analysis aims to determine the effect of the independent variable (X) on the dependent variable $(\mathrm{Y})$.

$$
\mathrm{Y}=\mathrm{a}+\mathrm{b} 1 \mathrm{X} 1+\mathrm{b} 2 \mathrm{X} 2+\mathrm{b} 3 \mathrm{X} 3+\mathrm{e}
$$

Information:

$\mathrm{Y}=$ Business Success

$\mathrm{a}=$ Constant

$\mathrm{X} 1=$ Entrepreneurial Spirit

$\mathrm{X} 2=$ Creativity

X3 $=$ Business Location

b1, b2, b3 = regression coefficient

e $=$ Standard error

Based on the multiple linear regression equation above, it can be explained as follows:

$\mathrm{Y}=-7.778+0.588 \mathrm{X} 1+0.485 \mathrm{X} 2+$ $0.474 \mathrm{X} 3+\mathrm{e}$

1. A constant value of -7.778 indicates that the success of SMEs is reduced by 7.778 , if the entrepreneurial spirit variable (X1), creativity (X2), business location (X3) is zero.

2. The regression coefficient (X1) for entrepreneurial spirit is 0.588 , indicating that if the entrepreneurial spirit (X1) changes one unit, the business success $(\mathrm{Y})$ increases by 0.588 , assuming creativity (X2), business location (X3) is fixed.

3. The regression coefficient (X2) for Creativity is 0.485 indicating that if Creativity (X2) changes by one unit, then Business Success (Y) increases by 0.485 , assuming an entrepreneurial spirit (X1), business location (X3) is fixed.

4. The regression coefficient (X3) of business location is 0.474 indicating that if the business location (X3) changes one unit, then Business Success (Y) increases by 0.474 , assuming an entrepreneurial spirit (X1), creativity (X2) is constant. 
The most dominant variable influencing the success of culinary SMEs in PPS can be analyzed using unstandardized coefficients beta by looking at the highest entrepreneurial spirit. In Table 4.13 above, it can be seen that the variable that has the highest value is the entrepreneurial spirit variable, which is 0.588 which is greater than creativity and business location is the most dominant factor affecting the success of the culinary UKM business in PPS.

\section{The Coefficient of Determination (R2)}

1. From the Adjusted R Square $=0.830$ can be said that the change in the dependent variable success of SMEs (Y) by $83 \%$ due to the variable entrepreneurial spirit (X1), creativity (X2), business location (X3), while the remaining $17 \%$ is caused by other factors not included in this model.

2. $\mathrm{R}$ square of 0.840 can be said that the variable entrepreneurial spirit (X1), creativity (X2), business location (X3), is able to explain the dependent variable for the success of SMEs (Y) by $84 \%$ while the remaining $16 \%$ is caused by other factors that are not in the model. this.

3. $\mathrm{R}=0.917$ means that the strong relationship between the independent variables $(\mathrm{X})$ together on the variable $(\mathrm{Y})$ is $91.7 \%$.

\section{Hypothesis Testing}

The hypothesis in this study is that there is an influence partially and simultaneously or jointly with the variables of entrepreneurial spirit (X1), creativity (X2), and business location (X3) on business success decisions (Y). Hypothesis testing is done by statistical techniques $t$ test (partial) and $\mathrm{F}$ test (simultaneous).

\section{t test (Partial)}

To determine the effect of each independent variable on the dependent variable partially, the $t$ test was conducted, following several stages of testing:
1. Significance level $\alpha / 2=0.05 / 2=0.025$ with $\mathrm{df}=\mathrm{n}-\mathrm{k}-1=51-3-1=47$. Then obtained ttable $=2.012$ The

2. criteria used in the $t$ test are:

a. If $\mathrm{t}$ count $>\mathrm{t}$ table $=\mathrm{H} 0$ is rejected and $\mathrm{Ha}$ is accepted, it means that partially there is an influence between entrepreneurial spirit, creativity and business location for business success.

b. If $\mathrm{t}$ count $\angle \mathrm{t}$ table $=\mathrm{H} 0$ is accepted and $\mathrm{Ha}$ is rejected, it means that partially there is no influence between entrepreneurial spirit, creativity and business location on business success.

The conclusions of the results are as follows;

1. Entrepreneurial Spirit

Based on the calculation obtained $t$ count (5.226)> t table (2.012) then $\mathrm{HO}$ accepted Ha rejected. So it can be concluded that the entrepreneurial spirit variable (X1) has a significant effect on the success of SMEs (Y).

2. Creativity

Based on the calculation obtained tcount (5.193)> ttable (2.012) then HO is accepted $\mathrm{Ha}$ is rejected. So it can be concluded that the variable creativity (X2) has a significant effect on the success of SMEs (Y).

3. Business Location

Based on the calculation obtained $t$ count (3.568) $>\mathrm{t}$ table (2.012) then $\mathrm{H} 0$ rejected $\mathrm{Ha}$ accepted. So it can be concluded that the business location variable (X3) has a significant effect on the success of SMEs (Y).

\section{F test (Simultaneous Test)}

$F$ test is used to jointly influence the independent variables on the dependent variable. The calculation of significance in the F test is calculated based on the $\mathrm{F}$ count and the significance is $0.05(5 \%)$. If the resulting $\mathrm{F}$ count is greater than $\mathrm{F}$ table with a significance level below 0.05 . So it means that all the 
independent variables together have a significant effect on the dependent variable.

Based on the calculation, it is obtained that Fcount (82.375)> Ftable (2.80) then $\mathrm{HO}$ is rejected. Ha is accepted, this is because $\mathrm{F}$ counts $82.375>\mathrm{F}$ table 2.80 . Thus it can be said that entrepreneurial spirit (X1), creativity (X2) and business location (X3) simultaneously affect business success (Y).

\section{Discussion}

Based on the research and analysis that researchers do by using tool SPSS, the researchers were able to interpret the results as follows:

1. In testing the partial hypothesis by using ttest between each independent variable and the dependent variable is:

a. The entrepreneurial spirit (X1)

By The results of hypothesis testing that have been carried out are obtained tcount 5,226> ttable 2,012 with a significance value of $5 \%$. Thus the entrepreneurial spirit is partially proven to have an effect on the success of culinary SMEs in PPS, according to the opinion of Eddy Soeryanto Soegoto (2009; 3).

b. Creativity (X2)

Based on the results of the hypothesis testing that has been carried out, it is obtained tcount 5.193> ttable 2.012 with a significance value of $5 \%$. Thus, creativity is partially proven to have an effect on the success of culinary SMEs in PPS, according to the opinion of Buchari Alma (2009; 72).

c. Business Location (X3)

Based on the results of hypothesis testing that has been carried out, it is obtained tcount 3.568> table 2.012 with a significance value of $5 \%$. Thus, business location is partially proven to have an effect on the success of culinary SMEs in PPS, in accordance with the opinion of Foster $(2008 ; 51)$.
2. Simultaneous hypothesis testing, the $\mathrm{F}$ value calculated $>$ Ftable is $82.375>2.80$ at the $5 \%$ significant level. So it can be interpreted that the variables of entrepreneurial spirit (X1), creativity (X2) and business location (X3) simultaneously proved to have a significant effect on the success of culinary SMEs in PPS

\section{CONCLUSION}

Based on the results of research on the Analysis of the Influence of entrepreneurial spirit, creativity and business location on business success in Culinary SMEs in the PPS (Pondok Permata Suci), Suci village, Manyar District, Gresik Regency, using multiple linear regression statistical analysis tools, the researchers can conclude: 1) Entrepreneurial spirit has a significant effect on the Business Success of Culinary SMEs in PPS (Pondok Permata Suci). The better the entrepreneurial spirit possessed by the owner of the Culinary UKM, the higher the Business Success of the Culinary UKM in PPS, 2) Creativity has a significant effect on the Success of the Culinary UKM in PPS (Pondok Permata Suci). The higher the creativity of the Culinary UKM, the higher the Business Success of the Culinary UKM in PPS, 3) Business Location has a significant effect on the Business Success of Culinary SMEs in PPS (Pondok Permata Suci). The more strategic the location of the culinary UKM business, the higher the business success of culinary UKM in PPS, 4) The results of hypothesis testing through the $F$ test (simultaneous) state that the variables of entrepreneurial spirit, creativity and business location simultaneously have a significant effect on the business success of culinary SMEs in PPS.

Based on the results of the analysis, discussion, and research conclusions above, the recommendations of the authors are as follows:1) For SMEs, the results of the t-test value of entrepreneurial spirit are higher than creativity and business location, so the smes/ukm must maintain the entrepreneurial 
spirit that is owned and continue to work deeper to be able to improve the quality of selfconfidence and dare to take risks in running the culinary business that is owned, 2) for future researchers, the results of this study can be used as a reference for future researchers by adding intervening variables and using different analysis techniques.

\section{REFERENCES}

Alma, Buchori (2009), Kewirausahaan untuk Mahasiswa dan Umum. Bandung: alfabeta

Benedicta Prihatin Dwi, Riyanti. (2003). Kewirausahaan Dari Sudut Pandang

Darmawan, Deni, (2014), Metode Penelitian Kuantitatif, Cetakan Kedua, Penerbit PT Remaja Rosdakarya, Bandung.

Diskoperindag Kabupaten Gresik (2016) Data jumlah sentra UKM Daerah Kabupaten Gresik

Diskoperindag Propinsi Jawa Timur (2016) Data pertumbuhan UKM Provinsi Jawa Timur

Endang Purwanti, Pengaruh Karakteristik Wirausaha,Modal Usaha, dan Strategi Pemasaran terhadap Perkembangan UMKM di Desa Dayaan dan Kalilondo Salatiga, (Jurnal Among Makarti, STIE AM Salatiga, 2012), hlm 21. Sumber : http://jurnal.stieama.ac.id.

Ghozali, (2011), Aplikasi Analisis Multivariate Dengan Program IBM SPSS 19, Edisi 5, Universitas Diponegoro, Semarang

http://blp-property.com/ diakses pada hari jumat tanggal 4 agustus 2017

https://gresikkab.bps.go.id/ diakses pada hari jumat tanggal 4 agustus 2017

Data UKM Kuliner di Perumahan PPS. Kantor Kelurahan Desa Suci,

Lestari, (2013), Pengaruh Jiwa Kewirausahaan dan Kreativitas Terhadap Keberhasilan Usaha Pada Sentra Industri Rajutan Binong Jati Bandung", Skripsi Manajemen, Universitas Komputer Indonesia Bandung.
Octavia, (2014), Pengaruh Sikap Kewirausahaan dan Kompetensi Wirausaha Terhadap Keberhasilan Usaha Pada Produsen Sepatu Cibaduyut Kota Bandung", Skripsi Manajemen, Universitas Komputer Indonesia Bandung.

Pamungkas, Hari Magnadi, (2014) Faktorfaktor Penentu Keberhasilan Usaha Pada Pemegang Usaha Waralaba (Studi Kasus Pada Usaha Waralaba Makanan dan Minuman Lokal Di Kota Semarang Jurnal Ekonomi, Vol. 3, No 1, Tahun: 2014, Universitas Diponegoro.

Rezki, Rahmad, (2014), Pengaruh Kualitas Produk, Harga, Lokasi Dan Promosi Terhadap Keputusan Pembelian Ruko Pada Cv. Sinar Jaya Global Steel Padang", Jurnal Ekonomi, Universitas Tamansiswa Padang

Santoso, Widowati, (2011), Pengaruh Kualitas Pelayanan, Fasilitas dan Lokasi Terhadap Keputusan Pembelian (Studi Kasus Pada Kopima USM)", Jurnal Ekonomi, Vol. 13, No 2, Tahun: 2011, Universitas Semarang.

Suarmawan, (2015), Analisis Faktor-faktor yang Mempengaruhi Keberhasilan Usaha Mikro dan Kecil (Studi pada Usaha Kerajinan Ingka di Desa Bulian, Kev. Kubutambahan)", Jurnal Ekonomi, Vol. 5, No.1, Tahun: 2015, Universitas Pendidikan Ganesha Singaraja

Sugiyono, (2017), Metode Penelitian Kuantitatif Kualitatif dan R\&D, Cetakan ke-25, Penerbit Alfabeta, Bandung

Suhardjono, (2003). Manajemen Perkreditan Usaha Kecil dan Menengah. Jakarta: UPP AMP YKPN Ikut Mencerdaskan Bangsa.

Suryana, 2017, "Kewirausahaan : Kiat dan Proses Menuju Sukses" Edisi 4, Cetakan ke-4, Penerbit Salemba Empat, Jakarta.

Tambunan, Tulus, T.H. (2006) Usaha Kecil dan Menengah di Indonesia Beberapa Isu Penting. Jakarta :PT Salemba Empat. 
Tjiptono, Fandy, (2008), Strategi Pemsaran, Edisi 3, ANDI: Yogyakarta.

Utami, Christina Whidya, (2014), Manajemen Ritel: Strategi dan Implementasi Operasional Bisnis Ritel Modern Di Indonesia, Edisi 2, Jilid 1, Penerbit Salemba, Jakarta.

Vivi Diah Kusumaningrum (2015) Analisis Pengaruh Karakteristik Wirausaha, Modal Usaha dan Strategi Pemasaran Terhadap Pengembangan UMKM Di Desa Bendungrejo kecamatan berbek kabupaten nganjuk.Skripsi UNP Kediri.

Wicaksono, Yudhi, (2010), Panduan Praktis

Buka Usaha dengan Modal Laptop, Elex Media Komputindo, Jakarta. 